\title{
Research
}

\section{Integrating Traditional and Evolutionary Knowledge in Biodiversity Conservation: a Population Level Case Study}

\author{
Dylan J.Fraser ${ }^{1}, \underline{\text { Thomas Coon }}^{2}, \underline{\text { Michael R. Prince }}^{3}, \underline{\text { Rene Dion }}^{4}$, and $\underline{\text { Louis Bernatchez }}^{5}$
}

\begin{abstract}
Despite their dual importance in the assessment of endangered/threatened species, there have been few attempts to integrate traditional ecological knowledge (TEK) and evolutionary biology knowledge $(\mathrm{EBK})$ at the population level. We contrasted long-term aboriginal TEK with previously obtained EBK in the context of seasonal migratory habits and population biology of a salmonid fish, brook charr, (Salvelinus fontinalis) inhabiting a large, remote postglacial lake. Compilation of TEK spanning four decades involved analytical workshops, semidirective interviews, and collaborative fieldwork with local aboriginal informants and fishing guides. We found that TEK complemented EBK of brook charr by providing concordant and additional information about (1) population viability; (2) breeding areas and migration patterns of divergent populations; and (3) the behavioral ecology of populations within feeding areas; all of which may ultimately affect the maintenance of population diversity. Aboriginal concerns related to human pressures on this species, not revealed by EBK, also help to focus future conservation initiatives for divergent populations and to encourage restoration of traditional fishing practices. However, relative to EBK, the relevance of TEK to salmonid biodiversity conservation was evident mainly at a smaller spatial scale, for example, that of individual rivers occupied by populations or certain lake sectors. Nevertheless, EBK was only collected over a 4-yr period, so TEK provided an essential long-term temporal window to evaluate population differences and persistence. We concluded that, despite different conceptual underpinnings, spatially and temporally varying TEK and EBK both contribute to the knowledge base required to achieve sustainability and effective biodiversity conservation planning for a given species. Such integration may be particularly relevant in many isolated regions, where intraspecific diversity can go unrecognized due to sparse scientific knowledge or undocumented TEK, and where governmental agencies and local communities increasingly seek to find common ground on which to address biodiversity issues.
\end{abstract}

Key Words: biodiversity; conservation; Cree; evolutionary biology; fish; James Bay; local ecological knowledge; migration; northern research; traditional ecological knowledge; traditional knowledge.

\section{INTRODUCTION}

Natural resource managers, conservation biologists, and local communities increasingly recognize that the success of any conservation initiative will hinge upon an interdisciplinary, pluralistic course of action. Consequently, the application of traditional ecological knowledge (TEK) to conservation issues has attracted growing attention in recent years (Gadgil et al. 1993, Berkes et al. 2000, Sheil and Lawrence 2004, Drew 2005). Defined as "knowledge, practice, and belief, evolving by adaptive processes and handed down through generations by cultural transmission, about the relationship of living beings, including humans, with one another and with their environment" (Berkes 1999:7), TEK has helped to guide efforts for protecting habitats of endangered or culturally important species (Johannes and Yeeting 2001, Nabhan 1992, 2000). In some cases, TEK has also assisted conservation planning focused below the species level (Table 1).

Recognition of TEK comes just as Western conservation science is acknowledging the importance of maintaining ecological and genetic diversity within species and the evolutionary processes that maintain it (Waples 1995, Fraser and

\footnotetext{
${ }^{1}$ Department of Biology, Dalhousie University, ${ }^{2}$ Cree Trapper's Association, ${ }^{3}$ Cree Nation of Mistissini, Quebec, ${ }^{4}$ Grand Council of the Crees of Quebec,

${ }^{5}$ Department of Biology, Laval University
} 
Table 1. Examples of traditional ecological knowledge (TEK) used in conservation planning below the species level.

\begin{tabular}{|c|c|c|c|}
\hline Species examples & TEK below the species level & Conservation implication & Reference \\
\hline $\begin{array}{l}\text { Caribou (Rangifer } \\
\text { tarandus) }\end{array}$ & $\begin{array}{l}\text { Historical abundance and spatial } \\
\text { distribution of the population from } \\
\text { southern Baffin Island, Canada }\end{array}$ & $\begin{array}{l}\text { Wildlife management: migration patterns } \\
\text { and harvest trends }\end{array}$ & $\begin{array}{l}\text { Ferguson \& Messier } \\
\text { (1997) }\end{array}$ \\
\hline $\begin{array}{l}\text { Bowhead whale } \\
\text { (Balaena mysticetus) }\end{array}$ & $\begin{array}{l}\text { Abundance and migration patterns along } \\
\text { the north coast of Alaska, USA. }\end{array}$ & Wildlife management and harvest trends & Huntington (2000) \\
\hline $\begin{array}{l}\text { Pacific herring } \\
\text { (Clupea pallasi) }\end{array}$ & $\begin{array}{l}\text { Important nursery areas and juvenile } \\
\text { distributions in Prince William Sound, } \\
\text { Alaska, U.S.A. }\end{array}$ & $\begin{array}{l}\text { Restoration of oil spill impacted } \\
\text { populations }\end{array}$ & Huntington (2000) \\
\hline $\begin{array}{l}\text { Green sea turtle } \\
\text { (Chelonia mydas) }\end{array}$ & $\begin{array}{l}\text { Knowledge of over-wintering habitat of a } \\
\text { population based on interactions with a } \\
\text { particular algae, Mexico }\end{array}$ & $\begin{array}{l}\text { Ecological interactions relating to } \\
\text { population distinction }\end{array}$ & Nabhan (2000) \\
\hline $\begin{array}{l}\text { Bumphead parrotfish } \\
\text { (Bolbometopon muric- } \\
\text { atum) }\end{array}$ & $\begin{array}{l}\text { Ontogenetic and associated habitat shifts } \\
\text { in a population in the Solomon Islands }\end{array}$ & $\begin{array}{l}\text { Protection of critical habitat at different } \\
\text { life history stages }\end{array}$ & $\begin{array}{l}\text { Aswani and Hamilton } \\
\text { (2004) }\end{array}$ \\
\hline Bonefish (Albula spp.) & $\begin{array}{l}\text { Historical trends in abundance, knowledge } \\
\text { of inshore habitats and of susceptibility to } \\
\text { different harvesting techniques for } \\
\text { populations, Kiribati }\end{array}$ & $\begin{array}{l}\text { Protection of remaining populations from } \\
\text { overfishing and habitat destruction }\end{array}$ & $\begin{array}{l}\text { Johannes and Yeeting } \\
\text { (2001) }\end{array}$ \\
\hline $\begin{array}{l}\text { Atlantic cod (Gadus } \\
\text { morhua) }\end{array}$ & $\begin{array}{l}\text { Differences in overwintering and } \\
\text { spawning behavior between populations in } \\
\text { Newfoundland, Canada }\end{array}$ & $\begin{array}{l}\text { Population discrimination at a local } \\
\text { geographic scale }\end{array}$ & Neis et al. (1999) \\
\hline $\begin{array}{l}\text { Brook charr } \\
\text { (Salvelinus fontinalis) }\end{array}$ & $\begin{array}{l}\text { Migration patterns between breeding and } \\
\text { feeding areas of different populations; } \\
\text { descriptions of breeding areas }\end{array}$ & $\begin{array}{l}\text { Conservation of different populations at } \\
\text { different life history stages } \\
\text { Fine-scale conservation efforts }\end{array}$ & This study \\
\hline $\begin{array}{l}\text { Brook charr } \\
\text { (Salvelinus fontinalis) }\end{array}$ & Harvest trends across multiple populations & $\begin{array}{l}\text { Trends in population abundance from } 40 \\
\text { yr ago to the present }\end{array}$ & This study \\
\hline $\begin{array}{l}\text { Brook charr } \\
\text { (Salvelinus fontinalis) }\end{array}$ & $\begin{array}{l}\text { Schooling behaviour in feeding areas and } \\
\text { fishing practices }\end{array}$ & $\begin{array}{l}\text { Maintenance of genetic diversity within } \\
\text { populations at small geographic scales }\end{array}$ & This study \\
\hline
\end{tabular}

Bernatchez 2001, Moritz 2002). This consideration of evolutionary biology knowledge (EBK) below the species level stems mainly from two concerns. First, conservation efforts focused solely at the species level might inadvertently jeopardize species viability and adaptability by overlooking important components of variation within species, and might ultimately ignore the possible germination of new species (Bowen 1999, Fraser and Bernatchez 2001). Second, a loss of intraspecific diversity can disfavor community species richness and limit ecosystem functioning or recovery (Booth and Grime 2003, Reusch et al. 2005).
The significance of integrating TEK and EBK in biodiversity conservation is highlighted by their expected dual incorporation into forthcoming assessments of endangered species or segments of species, both at national and international levels (e. g., UNEP 2004, COSEWIC 2005). Nevertheless, debate surrounds how both knowledge types can be used together (Berkes 1999, Turner et al. 2000). Reasons for this include the historical dismissal of TEK in decision making by Western resource management, unfamiliarity of research approaches between the biological and social sciences, concerns from TEK proponents over the molding of TEK into 
Western science without considering it on its own grounds, and the different conceptual underpinnings of both knowledge types (Berkes 1999, Davis and Wagner 2003, Ellis 2005). As a result, TEK and scientific knowledge are generally collected separately and rarely considered in parallel (but see Berkes 1999, Nabhan 2000, Donovan and Puri 2004, Moller et al. 2004).

Given increasing, economically driven resource use in many of the world's remaining isolated regions, integration of both knowledge types for biodiversity conservation may be especially pertinent here. Scientific research is often sporadic and seasonally limited in remote regions, whereas TEK may be geographically and temporally more extensive (Ferguson and Messier 1997, Berkes 1999). Intraspecific diversity in remote regions can also be evolutionarily young in origin, for instance, if found in postglacial environments, and may thus go unrecognized using binomial taxonomy (Taylor 1999). Moreover, with the growing interest in resource co-management in many isolated regions, based on partnerships between government agencies and local communities (BorriniFeyerabend 1996, Berkes 1999, 2004), some combination of Western and traditional science worldviews would be beneficial.

Salmonids are a socioeconomically and culturally important group of fishes in the northern hemisphere. Historically, their seasonal migratory movements provided predictable and abundant food sources for many aboriginal groups across North America. Consequently, aboriginal groups may possess a wealth of TEK regarding these fishes (e. g., Berkes 1977). The life cycle of migratory salmonids commonly involves breeding and rearing in freshwater streams followed by migration to ocean or lake feeding areas for growth and maturation. The subsequent homing of most individuals to natal streams for reproduction facilitates the development of numerous genetically distinct populations, and ultimately, local adaptations (Taylor 1991). Indeed, migratory salmonid populations often differ in morphological, migratory, and life-history traits, which are believed to have evolved mainly since the last Pleistocene glaciations, i.e., 8000 to 15,000 yr ago (Taylor 1991 , Quinn 2005). Such intraspecific diversity poses challenges to biodiversity conservation planning: it is not always clear how to best go about maintaining it (Waples 1995, Allendorf et al. 1997), and because of the legal implications associated with taxonomic status, salmonid taxonomy is often highly contentious (Allendorf et al. 2004, Irvine et al. 2005). Population diversity within salmonids thus provides a relevant backdrop for focusing on the integration of TEK and EBK.

Here, we integrate aboriginal TEK and previously obtained EBK to contribute to a conservation plan for migratory brook charr (Salvelinus fontinalis) populations inhabiting remote, postglacial Mistassini Lake ( $50^{\circ} 25^{\prime} \mathrm{N} 73^{\circ} 53^{\prime} \mathrm{W}$, Québec, Canada; Fig. 1). Known as màsimekw by the Eeyou Istchee Cree First Nations people who predominantly use the lake, the brook charr represents an important component of regional subsistence and recreational fisheries in the area (Flick 1977, Berkes et al. 1994, Fraser 2005). Elsewhere, the brook charr is a species of management interest because of its susceptibility to fishing and sensitivity to habitat alterations (Flick 1977, Power 1980, Curry et al. 2003). Due to increasing human population growth, fishing pressure and economic development in the Mistassini Lake region, as well as a lack of any documented regional traditional or scientific knowledge on this species, there is growing interest from the local community (CNM 2002) and government agencies in compiling knowledge of Mistassini Lake brook charr to facilitate its sustainability.

The spirit of our approach to integrating TEK and EBK in biodiversity conservation has two contexts. First, although they have different conceptual underpinnings, they are complementary to one another on the analogous value or belief of sustainability (Berkes 1999). That is, under several traditional knowledge paradigms, communityenforced rules for resource use help to maintain ecological processes and the species that mediate those processes (e.g., Alcorn 1993), whereas one element of Western conservation seeks to sustain processes leading to and maintaining biodiversity through management of human activities (e.g., Waples 1995, Fraser and Bernatchez 2001). Second, TEK and EBK equally boost the ecological knowledge base that is necessary for effective decision making to reach sustainability.

Our study includes five main components. We firstly review EBK of Mistassini Lake brook charr populations, obtained from scientific research conducted between 2000 and 2004. We then give an overview of traditional Cree community values and practices relating to the proper use of resources, 
Fig. 1. Geographic location of Mistassini Lake, Quebec in eastern North America, connecting rivers used as breeding grounds by migratory brook charr (Salvelinus fontinalis) in the lake, as well as the locations and family trapline designations of traditional hunting and fishing territories of informants interviewed in the study. Trapline designations follow those used by the local community of Mistissini, Quebec. To respect confidenciality of observations shared by individual informants, we have elected not to associate individual informant numbers (see Tables 3-5) with particular traplines.

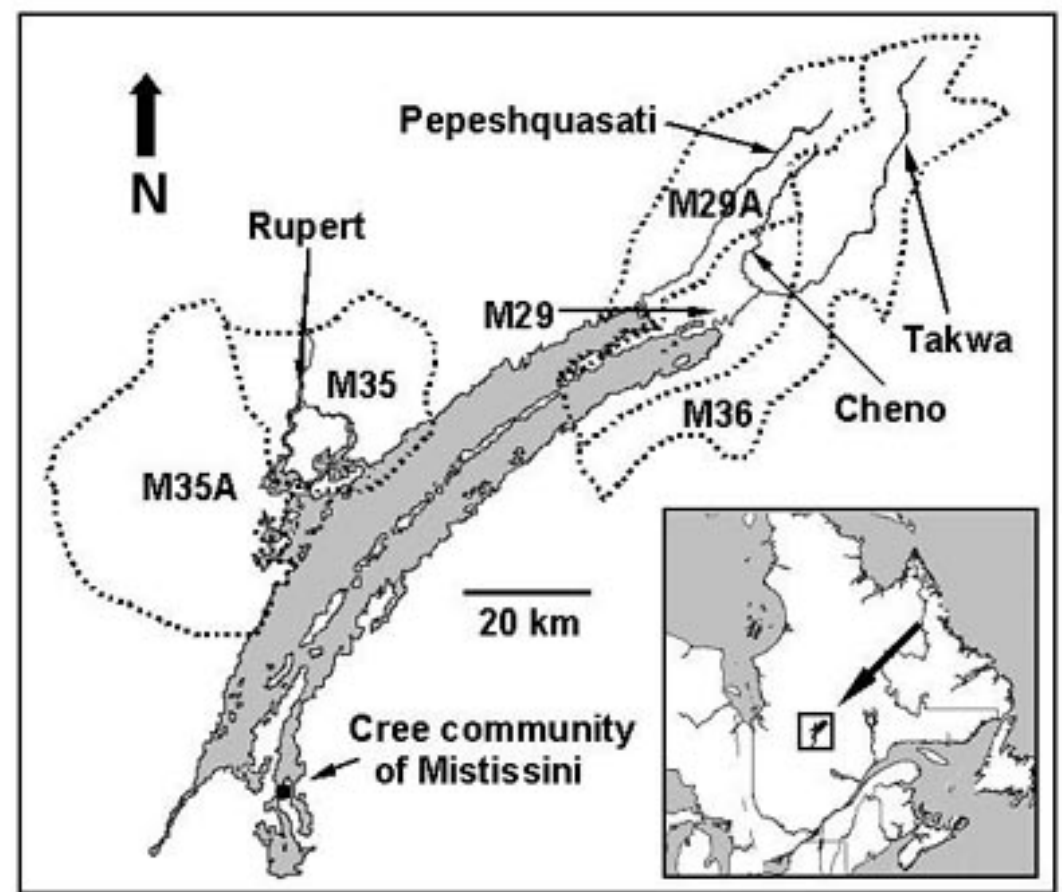

including brook charr. Third, we compile TEK of Mistassini Lake brook charr spanning the past four decades, including aboriginal concerns relating to the health of this species, using three complementary social science methods. Fourth, we examine similarities and differences between the TEK and EBK obtained, and discuss some unanticipated TEK that may affect the sustainability of different brook charr populations. Finally, we address how the integration of TEK and EBK can be implemented in an intraspecific biodiversity conservation plan for Mistassini Lake brook charr, which may have applications within other species.

\section{METHODS}

\section{Summary of evolutionary biology knowledge (EBK) at the population level}

From an evolutionary perspective, population diversity is thought to broadly evolve along two 
Fig. 2. Summer spatial distributions of outflow for the Rupert and inflow for the Pepeshquasati, Cheno, and Takwa populations of brook charr (Salvelinus fontinalis) in Mistassini Lake, according to scientific data from Fraser and Bernatchez (2005a). Genetic markers were used to assign individuals captured throughout the lake to their respective population of origin (details of methodology in Fraser and Bernatchez 2005a). Inflow populations are denoted in black because their spatial distributions did not differ from one another; the spatial distribution depicted is for the year 2001, but similar results were obtained for year 2000 (Fraser and Bernatchez 2005a). The size of the circles within the legend is proportional to the number of individuals assigned to populations at each sampling location.

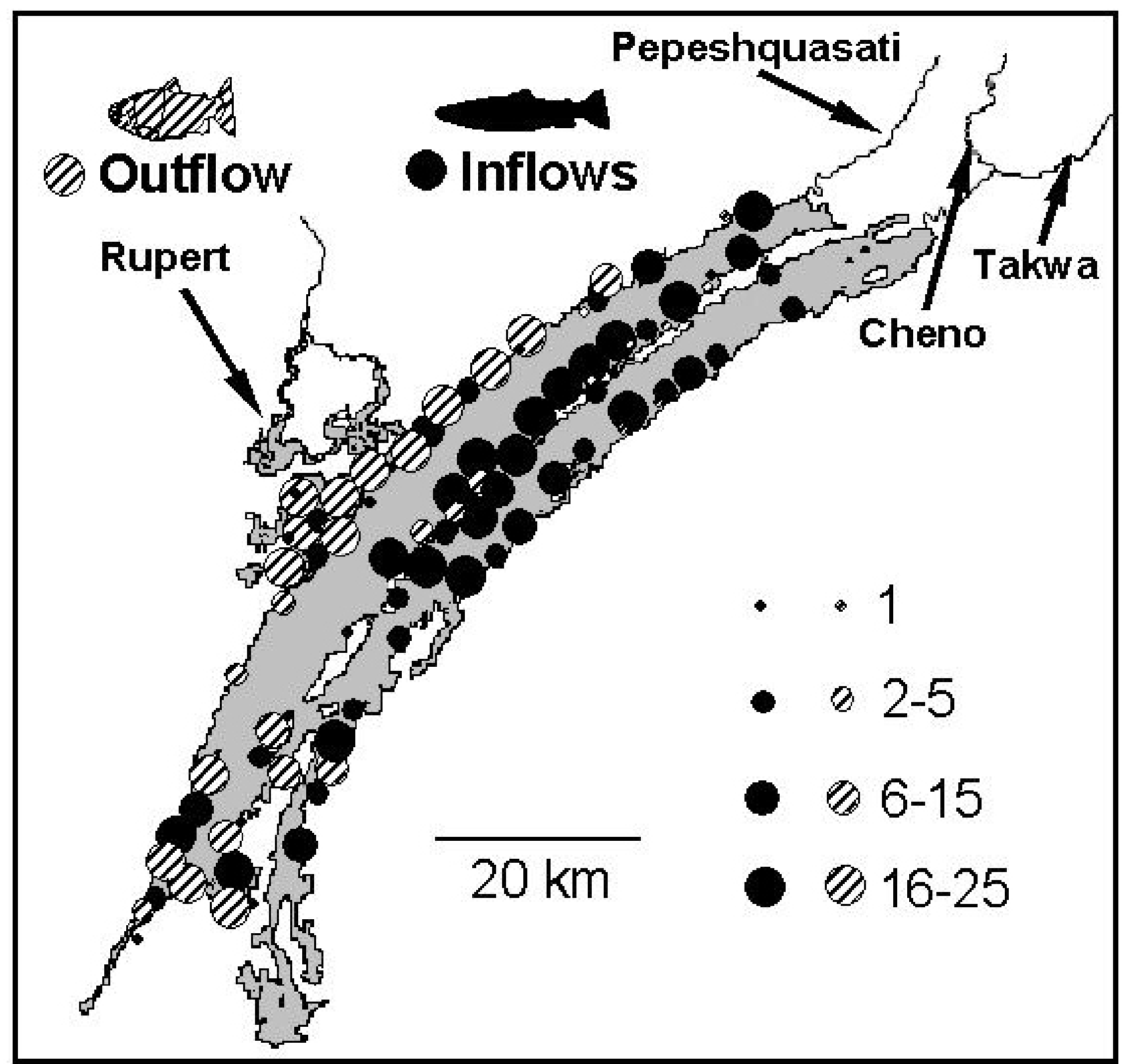


major axes. Natural selection can lead to adaptive genetic differences among populations, and/or populations with long, independent evolutionary histories may accumulate neutral genetic differences (Fraser and Bernatchez 2001, Moritz 2002). Consideration of both axes is important for intraspecific biodiversity conservation in Western conservation science. Recognition of adaptive differences helps to maintain heterogeneous landscapes, that is, the context of selection, and to ensure the viability of populations in present and future contexts. Recognition of historically isolated populations, or groups of populations within species is also essential. Indeed, it is difficult to recover such populations should they become extinct, because this would require long periods of isolation beyond human life spans (Moritz 2002).

Both axes have likely shaped the morphological, behavioral, and genetic diversity observed among Mistassini Lake brook charr populations. The most notable differentiation, and lowest gene flow, is found between populations breeding in the lake's outflow vs. three inflowing rivers, i.e., the Pepeshquasati, Cheno, and Takwa Rivers (Fig. 2 and Fraser et al. 2004). Inflow and outflow charr are distinguished by several characteristics: (1) longer vs. shorter migrations between breeding and feeding areas; (2) spatial segregation in their feeding areas within the lake associated with differential habitat selection (Fig. 2); (3) more streamlined vs. deeper body forms that relate to different migrations, e.g., the streamlined inflow charr form is known to improve swimming efficiency for long migrations in other salmonids; and (4) traits relating to divergent breeding habitats such as age-at-maturity and breeding time (Fraser et al. 2004, Fraser and Bernatchez 2005a). Similar traits have a genetic basis in other salmonids (e.g., Taylor and McPhail 1985), including in brook charr populations from the outflow's drainage (Perry et al. 2004).

Phenotypic differences among Mistassini Lake brook charr populations are, thus, negatively associated with the amount of gene flow that populations exchange. The differences relate to the divergent feeding and breeding areas that outflow and inflow populations occupy. When such relationships exist between phenotypic diversity, gene flow, and environmental factors, natural selection is strongly implicated in divergence (Endler 1977, Smith et al. 1997). However, inflow and outflow charr do not originate from a common ancestor, but from two different ancestral populations (Fraser and Bernatchez 2005b). Changes in the direction of discharge of Mistassini Lake occurred during its postglacial formation 7000 to $8000 \mathrm{yr}$ ago, and there is a correspondence between these changes and the directions by which each ancestral group colonized the lake. Details are found in Fraser and Bernatchez (2005b). Despite some gene flow upon contact in Mistassini Lake, outflow and inflow population groups maintain their distinctiveness. Due to their different ancestral origins, unique genetic differences may also have accumulated in history before colonization of Mistassini Lake took place.

In the context of a conservation plan for divergent charr populations, several other questions emerged from this research. Were migration characteristics of charr within individual rivers related to breeding and feeding areas temporally stable over the long term? Did local aboriginals traditionally recognize differences in charr within Mistassini Lake, i.e., in different lake sectors, rivers? Due to time and resource constraints, we were unable to determine how long charr stayed within rivers after entering them to breed each fall. Furthermore, within the outflow population, seasonal migratory movements of charr were more ambiguous; it was unclear whether some charr resided permanently in the river. A last question concerned the close genetic relationships of Pepeshquasati, Cheno, and Takwa inflow charr populations. Fraser et al. (2004) provided evidence that (1) charr were most abundant in Pepeshquasati, (2) charr within Takwa did not represent a genetically distinct population, and (3) individuals dispersing from Pepeshquasati to other inflows may have affected the demographic/genetic structuring of all three rivers. We were thus interested in what traditional ecological knowledge (TEK) was available regarding historical population trends and relationships between inflow charr.

\section{Summary of Cree community values and practices relating to the proper use of resources}

Like many other indigenous cultures of North America (e.g., see Salmon 2000, Turner et al. 2000), the Cree consider humans as part of the natural world. Humans are part of a community of beings, related to all fish and wildlife, and sharing the same Creator (Berkes 1999). Destruction of the natural world is, thus, a threat to human well being (Roué and Nakashima 2002). Traditional cultural beliefs 
of the Cree include the notion that animals control the hunt; it is the fish that decide to make themselves available to be caught (Berkes 1999). Accordingly, the more a fisher increases his respect for the fish, the more the fish become available and the more successful the fisher becomes. Respect for fish is shown in many ways, including in the processing of the animal and in the attitude of the fisher, i.e., humility. The continued use of resources such as fish is also important to achieve a sustainable harvest and maintain the fish's respect (Berkes 1999). However, fishers continuously monitor the environment such that although fish are killed, they are not diminished, so it is also tradition that fishing areas are rested periodically by rotating fishing sectors (Berkes 1999).

The Mistassini Cree have a communal form of territorial system associated with resource use. The communal territory, in this case surrounding the village of Mistissini, population 3000, located on the southeast shore of Mistassini Lake, is further subdivided into hunting and fishing territories of family groups (Speck 1915 and see Fig. 1 for examples). Senior hunters from each territory, known as tallymen, enforce the community's rules. Community members typically respect one another's territories and do not hunt or fish on other territories unless invited by members of that territory's family. However, Mistassini Lake itself is shared amongst all community members. Territories are culturally important for educating the young, including the social transmission of TEK (Ohmagari and Berkes 1997), and ensure high levels of productivity with limited hunting and fishing pressure (Berkes 1999). Such social organization may inadvertently stabilize pressure on resources by limiting the number of active hunters/fishers in particular areas (Berkes 1999), and we suggest that it may also inadvertently maintain intraspecific diversity in brook charr, at least within breeding areas.

For brook charr, traditional fishing effort in the Mistassini Lake region has been concentrated on territories where spawning and prespawning charr have entered the lake's outflow or inflows to breed at the beginning of autumn each year (Fig. 1). The Cree also concentrate brook charr fishing effort on feeding aggregations within Mistassini Lake itself each spring and early summer when these are found in shallow waters. Traditional fishing is guided by similar principles as in other Cree communities: by the need to consume a variety of foods and to contribute to the health of the community while minimizing waste (see Berkes 1999). In addition, as part of a sustainable harvest, the Mistassini Cree believe in leaving aggregating brook charr alone once an adequate supply of fish have been caught.

\section{Compilation of traditional ecological knowledge (TEK)}

\section{Analytical workshops}

During the course of the project from 2000-2004, we collected TEK on Mistassini Lake brook charr using three complementary methods. In all cases, TEK was recorded in a notebook and/or on 1:50,000 topographic maps. The first method involved the use of analytical workshops. These were based on consultation meetings and dialogue following oral presentations with groups of aboriginal informants, including 8 to 20 fishers from the local community. An advantage of this method is that the information provided may be supported by a consensus and allows both informants and scientists to better understand one another's perspectives (Johnson 1992, Huntington 2000). A disadvantage of this method is that some informants may not feel as comfortable as others to participate in the discussion (Ferguson and Messier 1997). Consultation meetings and presentations were conducted at the local band council building in the summers of 2000 2004 , with durations of 3-5 h.

\section{Semidirective interviews}

We also used semidirective interviews (sensu Nakashima 1990, Huntington 1998) with local aboriginal elder and fishing guide informants as a means of obtaining TEK. Interviews involved each informant being guided in a discussion by the interviewer with a general series of questions to cover important topics. These were carried out at the local Cree Trapper's Association, or at the individual's home (Table 2). The scope of the discussion was allowed to follow the observations made by the informant, and was also influenced by the applicability of certain questions according to the interest and expertise of the informant, and by the area of the informant's family trapline (see Fig. 1 for information on family traplines and for methodological purposes, see also Nakashima 1990, Ferguson and Messier 1997, Huntington 1998, 2000). Advantages of semidirective interviews include the acquisition of additional 
information not anticipated by the interviewer, without influence from other individuals (Ferguson and Messier 1997, Huntington 1998, 2000). They were also favored over previously planned written questionnaires because we realized after initial dialogues that many informants, especially elders, could not read or write in either their native language or in English.

Challenges with semidirective interviewing include the choice of individuals to be interviewed and how interviews should be weighted when making evaluations (Huntington 2000). We ensured the reliability of TEK in several ways. First, we only interviewed individuals that were considered local brook charr experts according to the local Cree Trapper's Association. These were male elder individuals with extensive guiding experience on the lake or rivers entering the lake, or male elder representatives from family traplines including Mistassini Lake's inflowing tributaries and outflow. The lack of female informants was expected according to local community advisors because women traditionally did not do as much of the fishing on family traplines as men, but may have also been due to the fact that all male hunting and fishing teams more frequently visit family traplines now than historically before Cree settled in permanent villages (George and Preston 1987). Second, the reliability of informants' information was judged by local feedback from several local advisors of the local Cree Trapper's Association. Third, whenever possible, we included multiple informants for areas of primary use of brook charr in the lake, e.g., feeding and breeding areas, to evaluate corroboration among informants' observations. Fourth, we chose elder or older individuals over younger individuals for interviews as other studies have done (Ferguson and Messier 1997, Huntington 1998, Usher 2000, Nichols et al. 2004), since they could provide information about brook charr biology over longer periods of $\sim 40 \mathrm{yr}$. Finally, interpreters chosen by the Cree Trapper's Association were used when necessary to accurately translate the native language into English. Interviewers and interpreters were male only.

A total of 20 informants were interviewed: of these, informants 1-5 and informants 6-13 were very familiar with the Rupert River outflow region of Mistassini Lake and the Pepeshquasati, Cheno, and Takwa inflowing rivers, respectively. Some of these informants also knew certain lake sectors very well. Remaining informants, 14-20, were from the local community of Mistissini and had fished certain lake sectors extensively. Interviews lasted from $3-5 \mathrm{~h}$. Interview duration depended on the scope of the information provided by the informant and the informant's comprehension of the questions being asked.

Each interview began with us outlining the objectives and procedures of the interview. We explained that we wanted information about the informant's own observations of brook charr or those of his parents, emphasizing that the information would be compiled into a report for a conservation plan of brook charr in the lake. All individuals interviewed understood the importance of their information for protecting brook charr for future generations. The series of general questions asked with respect to the seasonal migratory movements and population biology of outflow and inflow charr (Table 2) avoided leading questions such as "did charr move into the lake in June last year? We also avoided the use of scientific terminology in discussions, replacing terms such as "abundance" and "density" with "how many" (see Ferguson and Messier 1997, Huntington 1998). In addition, we clarified what the use of local expressions meant (see Briggs 1986, Huntington 2000). For instance, terms such as "fish" were confirmed to actually refer to màsimekw, i.e., brook charr, and not other fish species that are commonly exploited.

\section{Collaborative fieldwork}

A third and final method for obtaining TEK was frequent interaction with local aboriginal fishing guides through collaborative fieldwork. This occurred annually during the summers and falls of 2000-2002. Collaborative fieldwork offered a means of obtaining TEK over extended periods (Dowler 1996, Huntington 2000). It also enabled us to establish trust with individuals and to explain the benefits and importance of our scientific research for the local community and people (see Usher 2000). Additionally, it permitted us to show that our sampling techniques were not detrimental to the well being of individual brook charr. Depending on the sampling areas, collaborative fieldwork extended from $3 \mathrm{~d}-2 \mathrm{wk}$ in each area, and there were 6-10 sampling areas. 
Table 2. The general series of questions used as a guide for semidirective interviews.

\begin{tabular}{lc}
\hline Subject & General questions \\
\hline
\end{tabular}

Breeding area characteristics of outflow or inflow charr

Feeding area characteristics of outflow or inflow charr

Aboriginal concerns relating to human pressure on the species
Where and when were charr found within rivers, i.e., where did fishing take place?

How did the informant capture charr?

Did charr use the same or different areas for breeding each year?

Did charr spawn every year?

What did charr look like in appearance, e.g., color/shape/size?

Did all charr captured look the same or were there any differences in their size/shape/color?

Had the number of charr increased, decreased or stayed the same over the years since they had fished?

Where and when were charr found in the lake, i.e., where did fishing take place?

What techniques did the informant use to capture charr?

Did charr use the same or different areas for feeding in the lake each year? What did charr look like in appearance, e.g., color/shape/size?

Did all charr captured look the same or were there any differences in their size/shape/color?

Had the number of charr increased, decreased or stayed the same over the years since they had fished?

What factors might contribute to:

(1) Short-term or long-term changes in how many charr there are?

(2) Where charr moved around in the lake and rivers?

Did the informant have any concerns about the health of charr in the lake?

What could be done to protect brook charr for future generations?

\section{RESULTS}

\section{Summary of traditional knowledge (TEK)}

\section{Breeding area characteristics}

All informants familiar with either outflow, i.e., Rupert: 5/5, or inflow, i.e., Pepeshquasati, Cheno, Takwa: $8 / 8$, river breeding areas of brook charr described consistent dates in which charr enter and leave rivers to breed (Table 3). The major trend was for later breeding times in outflow charr (Table 3). Informant 3 indicated that outflow charr bred later than charr caught along the lake's island chain (Table 3), the latter likely being inflow charr depending on which population group was rvested in this region (Fig. 2). Body form descriptions of charr were also generally consistent within regions among informants commenting on this aspect, i.e., outflow, 5/5; inflows, 4/4, but revealed differences between outflow and inflow charr (Table 3).

Descriptions of breeding locations within rivers, exact locations not shown, were more variable among informants (Table 3). This suggested that informants knew certain but not all breeding grounds within rivers, or that charr did not use the same sites annually. For instance, outflow informants 1-3 explained that outflow charr bred in the same places each fall in some areas but not in others, e.g., some in the main river channel, some in shipastouks, i.e., side channels. These same informants stated that some breeding areas were no longer being used, even though historically, 25-75 charr were seen in the same areas within the main river channel $40 \mathrm{yr}$ ago. None of the 20 informants interviewed had seen or knew of breeding grounds within the lake. 
Migration distances between breeding areas and the lake described by informants ranged from $0-15 \mathrm{~km}$ in the outflow and $35-75 \mathrm{~km}$ in the inflows. The exact locations are not shown. For Cheno, this included the distance between its confluence with Takwa and the lake. There were some discrepancies among informants regarding the distance that charr migrate within Takwa. Large charr, $40-55 \mathrm{~cm}$, were captured mainly within the large pool below a $3 \mathrm{~m}$ falls, approximately $12 \mathrm{~km}$ upstream from its confluence with Cheno, and fewer downstream near Cheno, according to informant 11 and two community fishing guides. These same individuals stated that only smaller fish, $20-35 \mathrm{~cm}$, were captured above the falls over the past $40 \mathrm{yr}$, suggesting that that falls is a potential barrier to larger migrating charr from the lake. However, another fishing guide stated that larger charr, 40-55 $\mathrm{cm}$, were captured several kilometers upstream of the falls $20-30 \mathrm{yr}$ ago.

Of the eight inflow informants, three, i.e., 3, 12, and 13, had fished all three inflows 5-40 yr ago. They stated that the Pepeshquasati was the most productive river each fall, followed by the Cheno, and lastly the Takwa. Informant 20 stated that although rivers varied in abundance, all of them produced "good fishing" 20-30 yr ago. A good fishing day, historically, on the Pepeshquasati might be 50-75 charr from the same pool according to informant 6 . Three community fishers and informant 6 stated that after Cheno had been fished by a couple of fishers, the river needed a rest for a few days before good catches of charr were obtainable again. An informant with a family trapline on the Takwa, i.e., 11, M36, discussed that he never concentrated fishing only on brook charr because other species were much more abundant in his territory.

\section{Feeding area characteristics}

Descriptions of charr movement and distribution in the lake were less extensive than they were for breeding areas. Three of five informants knowledgeable of outflow charr, 1, 3, and 4, and three of seven informants knowledgeable of the lake, 14, 15, and 17 described feeding areas of large charr either west or east of the outflow that were consistent with informants' descriptions of outflow charr body form, as well as scientific data on the spatial distribution of this population group (Fig. 2, Table 3 vs. Table 4). Most outflow informants, 14 , also described important seasonal movements of charr of different sizes entering the outflow during the summer and early fall (Table 4). However, although community fishers and informants who commented specifically on outflow charr lake movements believed that larger charr from this river always used the lake and hence did not remain permanently in the river, they cautioned that they were not certain of this, and that they were also uncertain of smaller charr movements before July.

Other informants' descriptions of charr, i.e., their appearance, seasonal movements, inhabiting the island chain of the lake were consistent with scientific data in terms of the spatial distribution of inflow charr, their longer migrations within feeding areas, and body forms. For instance, informants 3 , 19, and 20 and two community fishers described charr captured along the island chain in the summer as being either long, skinny, or silvery in coloration, which is congruent with the more streamlined body form and spatial distribution of inflow charr according to evolutionary biological knowledge (Fig. 2, Table 4). It was not completely confirmed whether any charr resided permanently in inflows, but during the summer in the Pepeshquasati, only small charr, $<30 \mathrm{~cm}$, were traditionally caught, according to informants 6 and 7 .

\section{Aboriginal concerns or observations relevant for conservation}

The comments of most informants interviewed indicated an overall trend for a decline in the abundance of brook charr in Mistassini Lake over the past 30-40 yr (Table 5). This was evidenced by descriptions of poorer fishing capture efficiency in multiple lake sectors, fewer charr captured in gill nets in the rivers in which charr breed, a reduction in the number of charr seen on certain breeding grounds from hundreds to 10 or 20 according to informant 3 and a reduction in the average number of charr that form schools along the lake's island chain from 40-50 to 5-20 individuals according to informants 18 and 19, respectively. Collectively, negative impacts on brook charr populations were implicated in 19 of 21 different comments from 13 informants, including informants 5, 11, 13-15, and 17-20, or 23 of 25 comments including those of individual community fishers (Table 5). Additionally, of those informants that commented on the size of the charr they captured, four of six and one community fisher observed a reduction in charr size relative to past observations (Table 5). Informant 
Table 3. Summary of traditional ecological knowledge (TEK) for breeding area characteristics of brook charr reported by local experts of the community of Mistissini. When information was unavailable from particular experts, blank spaces are used. \#, each informant. Asterisks denote where community fishers and/or fishing guides made similar comments.

\begin{tabular}{|c|c|c|c|c|c|}
\hline Population group & $\begin{array}{l}\text { Inform- } \\
\text { ant \# }\end{array}$ & Breeding time & $\begin{array}{l}\text { Return to } \\
\text { lake }\end{array}$ & $\begin{array}{l}\text { Breeding site } \\
\text { locations }\end{array}$ & $\begin{array}{l}\text { Description of } \\
\text { appearance }\end{array}$ \\
\hline \multirow[t]{4}{*}{ Rupert Outflow } & 1,2 & $\begin{array}{l}\text { Mid- to late October, } \\
\text { generally in breeding } \\
\text { aggregations }\end{array}$ & February & $\begin{array}{l}\text { Main river, side } \\
\text { channels, } 0-15 \mathrm{~km} \\
\text { from rivermouth }\end{array}$ & $\begin{array}{l}\text { Short, deep-bodied, } \\
\text { very colorful }\end{array}$ \\
\hline & 3 & $\begin{array}{l}\text { Mid- to late October, later } \\
\text { than charr captured along } \\
\text { the lake's island chain }\end{array}$ & February & $\begin{array}{l}\text { Main river, side } \\
\text { channels, } 0-15 \mathrm{~km} \\
\text { from rivermouth }\end{array}$ & $\begin{array}{l}\text { Very wide with thick } \\
\text { tails }\end{array}$ \\
\hline & $4 *$ & $\begin{array}{l}\text { Mid- to late October, as late } \\
\text { as the end of November }\end{array}$ & January & Side channels & $\begin{array}{l}\text { Very wide with thick } \\
\text { tails }\end{array}$ \\
\hline & 5 & $\begin{array}{l}\text { Mid- to late October, to the } \\
\text { end of November, when ice } \\
\text { forms in backwaters }\end{array}$ & & $\begin{array}{l}\text { Main river, side } \\
\text { channels, } 0-15 \mathrm{~km} \\
\text { from rivermouth }\end{array}$ & $\begin{array}{l}\text { Short and fat; those } \\
\text { near the river mouth } \\
\text { more lean }\end{array}$ \\
\hline \multirow[t]{6}{*}{$\begin{array}{l}\text { Cheno, Pepeshquasati, } \\
\text { Takwa Inflows }\end{array}$} & 6 & $\begin{array}{l}\text { Late August to mid- } \\
\text { September, as late as the } \\
\text { end of October }\end{array}$ & $\begin{array}{l}\text { End of } \\
\text { November }\end{array}$ & $\begin{array}{l}\text { Main river, 35-75 km } \\
\text { from rivermouth; } \\
\text { Pepeshquasati }\end{array}$ & \\
\hline & 7 & $\begin{array}{l}\text { Late August to mid- } \\
\text { September }\end{array}$ & $\begin{array}{l}\text { End of } \\
\text { November }\end{array}$ & $\begin{array}{l}\text { Mouths of feeder } \\
\text { streams and side } \\
\text { channels }\end{array}$ & Long \\
\hline & $8,9,10$ & $\begin{array}{l}\text { Late August to mid- } \\
\text { September }\end{array}$ & & & \\
\hline & 11 & $\begin{array}{l}\text { Late August to early } \\
\text { October }\end{array}$ & December & $\begin{array}{l}\text { Takwa Pool below } \\
\text { falls }\end{array}$ & Sometimes silvery \\
\hline & 12 & $\begin{array}{l}\text { Late August to early } \\
\text { October }\end{array}$ & & $\begin{array}{l}\text { Large, slow pools, } 35 \\
\text { km+ from } \\
\text { rivermouth; Cheno }\end{array}$ & Long, very colorful \\
\hline & 13 & $\begin{array}{l}\text { Late August to mid- } \\
\text { September }\end{array}$ & December & & Long and fat \\
\hline
\end{tabular}

16 also noted that charr captured closer to the community had less fat and were weaker in appearance than they were in the past.

Some informants, i.e., 6/7 informants or fishers, stated that they were concerned about the increasing fishing pressure on charr, though this was not unanimous (Table 5). During discussions at analytical workshops, several community fishers expressed that aboriginal harvest limits were needed in the future, and that aboriginal fishing on breeding grounds after the fishing season for nonaboriginals was closed in September was a concern. Informants 3 and 20 also felt that both aboriginal and 
Table 4. Summary of traditional ecological knowledge (TEK) for brook charr feeding area characteristics reported by local experts of the community of Mistissini. When information was unavailable from particular experts, blank spaces are used. Asterisks denote when community fishers and/or fishing guides made similar comments.

\begin{tabular}{|c|c|c|}
\hline Informant \# & Seasonal movements and description of appearance & Dates \\
\hline $1,14,15$ & Large charr west of outflow along rocky shoals and islands & June-July \\
\hline 3 & $\begin{array}{l}\text { Large charr west of outflow along rocky shoals and islands; } \\
\text { charr caught east of outflow up to } 20 \mathrm{~km} \text { were very fat and deep- } \\
\text { bodied like fish found on fall breeding areas in the Rupert } \\
\text { outflow }\end{array}$ & June-August \\
\hline 4,17 & Large charr west of outflow along rocky shoals and islands & $\begin{array}{l}\text { Mainly June-July, but } \\
\text { sometimes until October }\end{array}$ \\
\hline $\begin{array}{l}1,2,3,4 \\
14\end{array}$ & $\begin{array}{l}\text { Colored charr of } 0.5-1 \mathrm{~kg} \text { arrived in outflow at the end of July; } \\
\text { larger charr of } 2-3 \mathrm{~kg} \text { arrived at the end of August and } \\
\text { September }\end{array}$ & Late July-September \\
\hline $3,18-20 *$ & $\begin{array}{l}\text { Charr frequently captured around rocky shoals and bays along } \\
\text { the lake's island chain traveled in schools }\end{array}$ & June-July \\
\hline $3,18-20 *$ & $\begin{array}{l}\text { Charr easiest to capture in June and the end of August in shallow } \\
\text { water }(0-5 \mathrm{~m})\end{array}$ & June-August \\
\hline 20 & "Waves" of charr move along island chain towards inflows & End of August \\
\hline $18-20$ & Charr captured along island chain moved around extensively & June-August \\
\hline $16,20^{*}$ & Long, silvery charr were captured along the island chain. & June-August \\
\hline 3 & $\begin{array}{l}\text { Charr captured along the island chain were paler and had less fat } \\
\text { than charr caught near or in the outflow. }\end{array}$ & June-July \\
\hline
\end{tabular}

nonaboriginal fishers must lower their limits of charr in the future.

\section{DISCUSSION}

With growing recognition that a holistic framework is necessary for effective resource management and biodiversity conservation, it has been argued that much work is still necessary to explore the ways in which Western and traditional knowledge can be used together (Gadgil et al. 1993, Berkes 1999, Huntington 2000, Sheil and Lawrence 2004, Drew 2005). The main objective of our study was to integrate traditional ecological knowledge (TEK) and evolutionary biology knowledge (EBK) at the population level, in order to assist biodiversity conservation planning within a species of salmonid fish, brook charr, in a remote subarctic region. There have been few attempts at such integration, despite the dual importance of both knowledge types in the assessment of endangered species or segments of species (e.g., UNEP 2004, COSEWIC 2005). In the ensuing discussion, we first discuss similarities and differences between TEK and EBK regarding brook charr, some unanticipated but relevant TEK that relates to the sustainability of different populations, and some factors that may have affected the acquisition of TEK from the local community. We then turn our attention toward the integration of 
Table 5. Aboriginal concerns relating to human pressures on brook charr in Mistassini Lake, according to local experts. Asterisks denote where community fishers and/or fishing guides made similar comments.

\begin{tabular}{|c|c|c|c|c|}
\hline $\begin{array}{l}\text { Geographic } \\
\text { location }\end{array}$ & Informant & Observation or concern & Trend & $\begin{array}{l}\text { Timeline of } \\
\text { observation }\end{array}$ \\
\hline \multirow[t]{4}{*}{ Outflow } & $2,3^{*}$ & Fishing efficiency & Declining & Past 40 yr \\
\hline & 3,4 & Numbers of charr observed on breeding grounds & Declining & Past $40 \mathrm{yr}$ \\
\hline & 1,3 & Fishing efficiency since opening of a fishing camp & Declining & Past 35 yr \\
\hline & 5 & Fishing efficiency; no major environmental changes & Same & Past 40 yr \\
\hline \multirow[t]{5}{*}{ Inflows } & 20 & Fishing efficiency in Cheno & Same & $5-30$ yr ago \\
\hline & 13 & Fishing efficiency in Cheno & Declining & $5-30$ yr ago \\
\hline & 11 & No major environmental changes in Takwa & Same & Past $35 \mathrm{yr}$ \\
\hline & $12 *$ & Fishing efficiency in Takwa & Declined & $25-30$ yr ago \\
\hline & 7 & Charr arriving later in the fall in Pepeshquasati & $\begin{array}{l}\text { Environmental } \\
\text { change }\end{array}$ & Past 35 yr \\
\hline \multirow[t]{9}{*}{ Lake } & $14,18-20^{*}$ & $\begin{array}{l}\text { Numbers of charr found in schools along the island } \\
\text { chain }\end{array}$ & Declining & Past 30 yr \\
\hline & $\begin{array}{l}14,15,17- \\
20^{*}\end{array}$ & Fishing efficiency in various lake sectors & Declining & Past 25 yr \\
\hline & $3,14 *$ & Fishing efficiency near the community & Declining & Past 40 yr \\
\hline & $4-6 *$ & Rapid access of all lake sectors with large boats & $\begin{array}{l}\text { Increasing fis- } \\
\text { hing pressure }\end{array}$ & Past $30 \mathrm{yr}$ \\
\hline & $8 *$ & $\begin{array}{l}\text { Numbers of boats with large horsepower boats and } \\
\text { their noise }\end{array}$ & $\begin{array}{l}\text { Increasing fis- } \\
\text { hing pressure }\end{array}$ & Past $10 \mathrm{yr}$ \\
\hline & 5 & Increased number of boats no major threat to charr & $\begin{array}{l}\text { Same fishing } \\
\text { pressure }\end{array}$ & Past $10-20 \mathrm{yr}$ \\
\hline & $3,8,16,19 *$ & Size of captured charr & Declining & Past $30 \mathrm{yr}$ \\
\hline & 8 & Size of captured charr & Same & Past 10 yr \\
\hline & 5 & Size of captured charr & Same & Past $10-20 \mathrm{yr}$ \\
\hline
\end{tabular}


TEK and EBK for intraspecific biodiversity conservation planning.

\section{Similarities and differences between TEK and EBK}

Congruence was found between TEK and EBK in certain aspects of seasonal migratory movements and population biology of brook charr, particularly with respect to descriptions of the appearance of charr captured in separate rivers, e.g., deep-bodied forms in the outflow vs. longer, more streamlined forms in the inflows, and the use of certain feeding areas in the lake, e.g., areas west of the outflow vs. the island chain. Given the time frame differences between TEK and EBK of 40 vs. $4 \mathrm{yr}$, these similarities between knowledge types are very important, since they suggest that ecological differences between outflow and inflow charr have been temporally stable over the long term. In fact, only informant 7 noted changes over time in seasonal movement, feeding areas, or the description of body forms of various charr.

The spatial scale at which observations were made was the most salient difference between TEK and EBK. With the exception of informant 3, aboriginals did not recognize differences among charr that used different regions of the lake or between its outflow and inflows. Brook charr were always described as màsimekw and never as multiple variants corresponding to regional sectors of the lake, as has been done by fishes in other cultures (Lobel 1978). Thus, TEK was most detailed at smaller spatial habitat scales such as individual rivers or specific lake sectors, and was less informative at a larger spatial scale of the entire lake. For instance, TEK provided detailed long-term descriptions of population biology within individual rivers with respect to: (1) the dates when charr entered individual rivers and were seen breeding, which suggested that charr reside within rivers for as long as 2-3 mo before returning to the lake; (2) the locations and characteristics of certain breeding grounds, e.g., breeding aggregations in the outflow, and (3) specific seasonal movements, which supported that inflow charr are predominantly migratory, whereas the outflow population apparently contains migratory, nonmigratory, or partially migratory components. Huntington (1998), Neis et al. (1999) and Moller et al. (2004) also note that TEK provides additional, and often more detailed information than scientific data at finer geographic scales.
The large size of Mistassini Lake, $2150 \mathrm{~km}^{2}$, might have made it difficult, historically, for many fishers to fish large regions of the lake. On the other hand, it is a Cree cultural norm for individuals to respect one another's family trapline boundaries, therefore, most individuals only know their own trapline areas well. However, this would not negate the sharing of observational differences between territories unless territorial ownership opposed tribal sharing of knowledge, or if this species was less important, historically, for survival as were other species. The latter explanation is more plausible, given that the Cree are a gregarious people. For example, knowledge sharing was considered an obligation to the health of the local community (Berkes 1999), and there are no specific ceremonies involving brook charr in contemporary Mistassini Cree culture.

One exception to the lack of TEK at larger spatial scales involves informants $3,12,13$, who had fished all three inflows in the fall 5-40 yr ago), and who indicated that the Pepeshquasati was the largest producer of fish over several years, and often several times over a fishing season. Other descriptions of fishing at inflows also provided indirect evidence as to the potential historical productivity and persistence of these three rivers. In light of the close genetic relationships between charr from different inflows (Fraser et al. 2004), this knowledge is relevant for affirming probable population trends among inflows over a temporal scale beyond those based on scientific data alone. Nevertheless, as with the available scientific data, there were some discrepancies within TEK pertaining to inflows. For instance, it is not entirely clear how far charr can migrate from the lake up the Pepeshquasati River, and whether the large charr captured below the falls and the small charr found above them originate from the same or separate gene pools. As a result, both TEK and EBK should be ideally reexamined in this river because of limited information currently available to resource managers.

\section{Unanticipated TEK: behavioral ecology in feeding areas}

Semidirective interviewing provided unexpected insight into the behavioral ecology of charr among feeding areas that may affect the maintenance of population diversity. Several informants told us that brook charr along the lake's island chain form schools. Two of these informants reported that the harvest of entire schools was traditionally 
discouraged by cultural norms because this would "eliminate entire families." The consequence of this rule was that schools, and the vicinities they frequented, were left alone once a few individuals had been captured. Using genetic data, this allowed us to test and support the hypothesis that a considerable proportion of individuals within schools were in fact full- or half-siblings (Fraser et al. 2005).

The implication here is that certain individuals possessing TEK had some idea of fish behavioral factors that may indirectly affect their population diversity and health. Such a traditional practice of harvesting partial schools and rotating fishing areas might ensure what Berkes et al. (2000) have termed as "reproductive resilience" in brook charr. Inadvertently or not, by only partially harvesting different schools of charr for subsistence, the Cree reduce the genetic impact of fishing because the selection pressure is distributed amongst different charr genotypes. Such unexpected insights reiterate the advantage of posing open-ended questions when considering TEK in a resource management or a biodiversity conservation context (see Huntington 1998).

\section{Factors affecting the acquisition of TEK}

Recent studies and essays have noted that extracting available TEK in its entirety may be difficult due to cultural, communication, or language issues (Ferguson and Messier 1997, Wenzel 1999, Huntington 2000, Turner et al. 2000, Usher 2000, Drew 2005). Throughout this study, we consulted community officials to identify key informants for the interviews and fieldwork (see Ferguson and Messier 1997, Huntington 1998, 2000, Davis and Wagner 2003). Most individuals were willing to share their TEK once we had gained their trust and affirmed their confidentiality, and once they recognized the importance of our work for their community. However, a few individuals were reluctant to be interviewed. It is also possible that informants might have excluded some reliable information, since they occasionally played down the certainty of their memories (see also Ferguson and Messier 1997). Nevertheless, the concordance of information provided by multiple informants from the same areas in many instances suggests that TEK was of consensus.

We were unable to break down the responses according to the ages of the informants. This was because the availability of key informants in the local community was modest among lake regions, and there were potential cultural difficulties with respect to asking some of the individuals their ages. However, in future studies, it might be useful to compare information provided by individuals of different ages, as this could reveal environmental changes not apparent within shorter time frames. For instance, among the informants and community fishers that commented on the size of captured charr, those with longer lake fishing experience over the past $30 \mathrm{yr}$ observed a reduction in charr size, whereas those with 10-20 yr of lake fishing experience did not (Table 5).

Within the local community, TEK was scattered amongst many individuals. The extent of the knowledge about charr varied among individuals, perhaps because on certain family traplines, charr were not as abundant or reliable as food sources relative to other fish species. Indeed, territorybased, microgeographic knowledge differences among fish and wildlife are an important component of Cree family culture (Preston 1975). The successful transmission of TEK likely also depended on how long families spent time with one another on traplines, which may have been recently affected by Cree cultural changes in the past half century (George and Preston 1987, Ohmagari and Berkes 1997). Other studies attempting to compile traditional/local knowledge have also noted that the breadth of TEK from separate individuals may vary (Huntington 1998, Neis et al. 1999, Gilchrist et al. 2005). More generally, although brook charr are an important food source for Cree, they are secondary to certain mammals such as beaver, birds such as goose, and other fish species such as lake trout, $S$. namaycush); thus, the extent of TEK for charr may be more limited than it is for other species (see Hunn 1993, Gilchrist et al. 2005).

From the standpoint of biological researchers interested in collaborating with local people, the factors affecting the acquisition of TEK in our study demonstrate that considerable time is required to collect it properly. Therefore, It might be more practical for biologists to collaborate with social scientists who have similar conservation interests at the onset of a project. We wish to point out, however, that because we incorporated TEK into our scientific research through collaboration since the beginning of the project, the time taken to obtain TEK was easily repaid by the resources we saved in finding appropriate sampling sites and in obtaining sufficient samples at the most appropriate 
times. Additionally, perceptions by the community of our research intentions as scientists likely benefited from our efforts to integrate TEK into our research planning.

\section{Integration of TEK and EBK in biodiversity conservation planning}

Further collaboration of scientists and local people will be important for many biodiversity conservation issues around the world. Attempts to integrate TEK with scientific knowledge such as EBK can help researchers to gain trust and foster effective communication in remote or aboriginal communities (Sheil and Lawrence 2004). Such integration helps biologists to better understand aboriginal concerns, their livelihoods and the precision of their TEK. Indeed, there are clearly risks of impeding conservation efforts if biologists believe that they can arrive in unfamiliar regions and properly conserve species or populations without respecting TEK (Johannes 1989, Pierotti and Wildcat 2000). Integrative research may also increase the likelihood that local people will recognize and accept the importance of biodiversity conservation value associated with EBK.

Although there are clearly benefits of communication, collaboration, and trust, the integration of TEK and EBK also has tangible benefits for developing sound conservation plans. Notably, under the common ground of sustainability, we argue that the parallel consideration of TEK and EBK is complementary for biodiversity conservation. The maintenance of ecological processes and the species that mediate those processes for human well being is embodied in many TEK resource uses and practices (Alcorn 1993, Berkes 1999). Similarly, sustaining the processes leading to and maintaining biodiversity, via the management of human activities, is a general goal of contemporary conservation biology, namely extinction prevention and the recognition of intraspecific diversity (Waples 1995, Fraser and Bernatchez 2001). Though the motives of each knowledge type are not entirely the same, the unique ecological insight gained from each contributes to the knowledge base required to achieve sustainability.

For the conservation of intraspecific diversity of Mistassini Lake brook charr, the complementarity of ecological insight provided by TEK and EBK may lie in the acceptance that each knowledge type has its strengths, but not at the same temporal and spatial scales. For instance, research involving EBK provides a scientifically-based, lakewide perspective on the ancestral relationships and genetic structure of populations, the phenotypic differences related to local environments and local adaptations, and the spatial use of different populations at various life cycle stages when charr may be exposed to a variety of human activities. The combination of these data illustrates that divergent outflow and inflow population groups each represent a component of the biodiversity of brook charr within the lake ecosystem. Recognizing and maintaining divergent populations and the habitats that they occupy during different parts of the life cycle should thus be a primary biodiversity conservation initiative to ensure that the long-term potential of this species to respond to environmental changes is maximized.

Although TEK may be of a more qualitative nature than EBK, it conversely revealed long-term trends on the viability of divergent populations in this region that were not achievable with scientific data. A focus on fine-scale conservation efforts within populations, such as the identification of important breeding sites worthy of protection, was also facilitated by TEK. In addition, TEK identified several proximate and ultimate threats to brook charr populations that need recognition if sustainability under TEK and EBK is to be achieved. Notably, despite the remote and relatively pristine condition of the Mistassini Lake ecosystem, most informants expressed concerns regarding declining numbers and catchability of charr, or changes in charr body condition and/or charr size in certain areas over the past four decades. Informants also described new patterns in human activities that may have an impact on charr behavior, i.e., noise from large boats, and these might be easily dismissed by Western science.

Until now, the Cree cultural territory system of family traplines may have inadvertently contributed to maintaining intraspecific diversity of brook charr. For instance, such territories have likely reduced the access of all fishers to important brook charr breeding areas. There may also have been more incentive to conserve brook charr on these traplines, since these families likely depended more historically on this species for subsistence than did those relying on other traplines. However, brook charr are highly migratory within Mistassini Lake and in their feeding areas, and arguably, areas where TEK is less comprehensive than EBK, are open 
access to the entire community. In the face of increasing human population growth in the local Cree community and the observations by local people about resource depletion, the persistence of brook charr for future generations will require the community to integrate both local and scientific values into decision making. At a minimum, this could include: (1) the restoration of traditional Cree fishing practices such as the temporal rotation of fishing areas and the partial harvesting of brook charr schools; (2) continual, qualitative population monitoring of family traplines that harbor important breeding areas for divergent populations; (3) consideration of the different feeding areas used by divergent populations; and (4) collaboration and feedback between local community members and scientists to obtain quantitative information about charr population trends and harvests.

The above discussion likely typifies the challenges related to biodiversity conservation planning for a given species in other isolated regions of the world. That is, either knowledge type in isolation, TEK or EBK, applied to Mistassini Lake is insufficient alone to recognize simultaneously the diversity within brook charr, the processes and environments that lead to and maintain diversity, and the threats to the viability of this species. As a result, our study demonstrates that both modes of thinking are required to implement the practices necessary for achieving a balance between biodiversity conservation and sustainability.

Responses to this article can be read online at:

http://www.ecologyandsociety.org/vol11/iss2/art4/responses/

\section{Acknowledgments:}

This study would not have been possible without the collaboration of the Cree Nation of Mistissini and the many individuals of the town of Mistissini, Quebec, Canada, who shared their TEK of brook charr with us or who helped us find the right people during the course of our research, particularly: J. Loon, K. Bryant, S. Cooncome, R. Cooncome, S. Shecapio, M. Shecapio, G. Shecapio, J. Husky, T. Voyageur, S. Petawabano, G. Longchamp, J. Rabbitskin, A. Mark, R. Mark, J. Coon, I. Coon, K. Coon, J. Swallow, C. Coonishish, J. Jolly., R. Gunner, E. Awashish, I. Iserhoff, L. Iserhoff, D. Iserhoff, D. Mianscum, S. Mianscum, L. Mianscum,
N. Neeposh, E. Cooncome, M. Cooncome, M. Trapper, D. Gunner and C. Jimiken. Comments from A. Calvert, B. Fraser, D. Hardie, and C. Morrison greatly improved the quality of the manuscript. Funding was provided by a National Sciences and Engineering Research Council of Canada (NSERC) Grant to $L B$, and by a Field Grant from the Eeyou Namess Corporation (Montreal) to LB and DJF. DJF was supported by NSERC Doctoral and Northern Research Scholarships.

\section{LITERATURE CITED}

Alcorn, J. B. 1993. Indigenous peoples and conservation. Conservation Biology 7:424-426.

Allendorf, F. W., D. Bayles, D. L. Bottom, K. P. Currens, C. A. Frissell, D. Hankin, J. A. Lichatowich, W. Nehlsen, P. C. Trotter, and T. H. Williams. 1997. Prioritizing Pacific salmon stocks for conservation. Conservation Biology 11:140-152.

Allendorf, F. W., R. F. Leary, N. P. Hitt, K. L. Knudsen, L. L. Lundquist, and P. Spruell. 2004. Intercrosses and the U.S. Endangered Species Act: should hybridized populations be included as Westslope cutthroat trout? Conservation Biology 18:1203-1213.

Aswani, S., and R. J. Hamilton. 2004. Integrating indigenous ecological knowledge and customary sea tenure with marine and social science for conservation of bumphead parrotfish (Bolbometopon muricatum) in the Roviana Lagoon, Solomon Islands. Environmental Conservation 31:69-83.

Berkes, F. 1977. Fishery resource use in a subarctic Indian community. Human Ecology 5:289-307.

Berkes, F. 1999. Sacred ecology: traditional ecological knowledge and resource management. Taylor and Francis, Philadelphia, Pennsylvania, USA.

Berkes, F. 2004. Rethinking community-based conservation. Conservation Biology 18:621-630.

Berkes F., P. J. George, R. J. Preston, A. Hughes, J. Turner, and B. D. Cummins. 1994. Wildlife harvesting and sustainable regional native economy in the Hudson and James Bay Lowland, Ontario. 
Arctic 47:350-360.

Berkes, F., J. Colding and C. Folke. 2000. Rediscovery of traditional ecological knowledge as adaptive management. Ecological Applications 10:1251-1262.

Booth, R. E., and J. P. Grime. 2003. Effects of genetic impoverishment on plant community diversity. Journal of Ecology 91:721-730.

Borrini-Feyerabend, G. 1996. Collaborative management of protected areas: tailoring the approach to the context. International Conservation Union (IUCN), Gland, Switzerland. Available online at: http://www.iucn.org/themes/spg/Files/tailor. html/.

Bowen, B. W. 1999. Preserving genes, species, or ecosystems? Healing the fractured foundations of conservation policy. Molecular Ecology 8:S5-S10.

Briggs, C. L. 1986. Learning how to ask: a sociolinguistic appraisal of the role of the interview in social science research. Cambridge University Press, Cambridge, UK.

Committee on the Status of Endangered Wildlife in Canada (COSEWIC). 2005. Canadian species at risk. Canadian Wildlife Service, Environment Canada, Ottawa, Ontario, Canada.

Cree Nation of Mistissini (CNM). 2002. Mistassini Lake fish study. Council of the Cree Nation of Mistissini, Mistissini, Quebec, Canada.

Curry, R. A., C. Brady and G. E. Morgan. 2003. Effects of recreational fishing on the population dynamics of lake-dwelling brook trout. North American Journal of Fisheries Management 23:35-47.

Davis, A., and J. R. Wagner. 2003. Who knows? On the importance of identifying 'experts' when researching local ecological knowledge. Human Ecology 31:463-489.

Donovan, D., and R. Puri. 2004. Learning from traditional knowledge of non-timber forest products: Penan Benalui and the autecology of Aquilaria in Indonesian Borneo. Ecology and Society 9:3. URL: http://www.ecologyandsociety.org/ vol9/iss 3/art3/.
Dowler, D. 1996. The use of traditional knowledge by the Fisheries Joint Management Committee in the Inuvialuit Settlement Region. Pages 62-63 in A. Fehr and W. Hurst, editors. A seminar on two ways of knowing: indigenous and scientific knowledge. Aurora Science Institute, Inuvik, Northwest Territories, Canada.

Drew, J. A. 2005. Use of traditional ecological knowledge in marine conservation. Conservation Biology 19:1286-1293.

Ellis, S. C. 2005. Meaningful consideration? A review of traditional knowledge in environmental decision making. Arctic 58:66-77.

Endler, J. A. 1977. Geographic variation, speciation, and clines. Princeton University Press, Princeton, New Jersey, USA.

Ferguson, M. A. D., and F. Messier. 1997. Collection and analysis of traditional ecological knowledge about a population of Arctic tundra caribou. Arctic 50:17-28.

Flick. W.A. 1977. Some observations, age, growth, food habits and vulnerability of large brook trout (Salvelinus fontinalis) from four Canadian lakes. Naturaliste Canadienne 104:353-359.

Fraser, D. J. 2005. Étude de la divergence populationnelle chez l'omble de fontaine: intérêt à l'évolution et la bioconservation. Dissertation. Université Laval, Sainte-Foy, Québec, Canada.

Fraser, D. J., and L. Bernatchez. 2001. Adaptive evolutionary conservation: towards a unified concept for defining conservation units. Molecular Ecology 10:2741-2752.

Fraser, D. J., C. Lippé, and L. Bernatchez. 2004. Consequences of unequal population size, asymmetric gene flow, and sex-biased dispersal for population structure in brook charr (Salvelinus fontinalis). Molecular Ecology 13:67-80.

Fraser, D. J. and L. Bernatchez. 2005a. Adaptive migratory divergence among sympatric brook charr populations. Evolution 59:611-624.

Fraser, D. J. and L. Bernatchez. 2005b. Allopatric origins of sympatric brook charr populations: colonization history and admixture. Molecular Ecology 14:1497-1509. 
Fraser, D. J., P. Duchesne, and L. Bernatchez. 2005. Migratory charr schools exhibit population and kin associations beyond juvenile stages. Molecular Ecology 14:3133-3146.

Gadgil, M., F. Berkes, and C. Folke. 1993. Indigenous knowledge for biodiversity conservation. Ambio 22:151-156.

George, P., and R. Preston. 1987. "Going in between": the impact of European technology on the work patterns of West Main Cree in Northern Ontario. Journal of Economic History 47:447-460.

Gilchrist, G., M. Mallory, and F. Merkel. 2005. Can local ecological knowledge contribute to wildlife management? Case studies of migratory birds. Ecology and Society 10:20.

Hunn, E. 1993. The ethnobiological foundation for TEK. Pages 16-20 in N. M. Williams and G. Baines, editors. Traditional ecological knowledge: wisdom for sustainable development Centre for Resource and Environmental Studies, Australian National University, Canberra, Australia.

Huntington, H. P. 1998. Observations and utility of the semi-directive interview for documenting traditional ecological knowledge. Arctic 51:237-242.

Huntington, H. P. 2000. Using traditional ecological knowledge in science: methods and applications. Ecological Applications 10:1270-1274.

Irvine, J. R., M. R. Gross, C. C. Wood, L. B. Holtby, N. D. Schubert, and P. G. Amiro. 2005. Canada's Species At Risk Act: an opportunity to protect "endangered" salmon. Fisheries 30:11-19.

Johannes, R. E. 1989. Traditional ecological knowledge: a collection of essays. IUCN, Cambridge, UK.

Johannes, R. E., and B. Yeeting. 2001. I-Kiribati knowledge and management of Tawara's marine resources. Atoll Research Bulletin 489:1-24.

Johnson, M. 1992. Capturing traditional environmental knowledge. Dene Cultural Institute and International Developmental Research Centre, Ottawa, Ontario, Canada.

Lobel, P. S. 1978. Gilbertese and Ellice islander names for fishes and other organisms. Micronesia 14:177-197.

Moller, H., F. Berkes, P. O'Brian-Lyver, and M. Kislalioglu. 2004. Combining science and traditional ecological knowledge: monitoring populations for co-management. Ecology and Society 9:2.

Moritz, C. 2002. Strategies to protect biological diversity and the evolutionary processes that sustain it. Systematic Biology 51:238-254.

Nabhan, G. P. 1992. Threatened Native American plants. Endangered species update 9:1-4.

Nabhan, G. P. 2000. Interspecific relationships affecting endangered species recognized by O'Odham and Comcaac cultures. Ecological Applications 10:1288-1295.

Nakashima, D. J. 1990. Application of native knowledge in EIA: Inuit, elders, and Hudson Bay oil. Canadian Environmental Assessment Research Council, Ottawa, Ontario, Canada.

Neis, B., D. C. Schneider, L. Felt, R. L. Haedrich, J. Fischer, and J. A. Hutchings. 1999. Fisheries assessment: what can be learned by interviewing resource users? Canadian Journal of Fisheries and Aquatic Sciences 56:1949-1963.

Nichols T., F. Berkes, D. Jolly, N. B. Snow, and the Community of Sachs Harbour. 2004. Climate change and sea ice: local observations from the Canadian Western Arctic. Arctic 57:68-79.

Ohmagari, K., and F. Berkes. 1997. Transmission of indigenous knowledge and bush skills among the Western James Bay Cree women of Subarctic Canada. Human Ecology 25:197-222.

Perry, G. M. L., C. Audet, B. Laplatte, and L. Bernatchez. 2004. Shifting patterns in genetic control at the embryo-alevin boundary in brook charr. Evolution 58:2002-2012.

Pierotti, R., and D. Wildcat.2000. Traditional ecological knowledge: the third alternative (commentary). Ecological Applications 10:1333-1340.

Power, G. 1980. The brook charr, Salvelinus fontinalis. Pages 141-203 in E. K. Balon, editor. Charrs: salmonid fishes of the genus Salvelinus. W. 
Junk, The Hague, Netherlands.

Preston, R. 1975. Cree narrative: expressing the personal meaning of events. National Museum of Man Mercury Series, Canadian Ethnology Service Paper Number 30, National Museum of Canada, Ottawa, Ontario, Canada.

Quinn, T. P. 2005. The behavior and ecology of Pacific salmon and trout. University of Washington Press, Seattle, Washington, USA.

Reusch, T. B., A. Ehlers, A. Hammerli, and B. Worm. 2005. Ecosystem recovery after climatic extremes enhanced by genotypic diversity. Proceedings of the National Academy of Science of the United States of America 102:2826-2831.

Roué, M., and D. Nakashima. 2002. Knowledge and foresight: the predictive capacity of traditional knowledge applied to environmental assessment. International Science Journal 54(173):337-347.

Salmon, E. 2000. Kinentric ecology: indigenous perceptions of the human-nature relationship. Ecological Applications 10:1327-1332.

Sheil, D., and A. Lawrence. 2004. Tropical biologists, local people, and conservation: new opportunities for collaboration. Trends in Ecology and Evolution 19:634-638.

Smith, T. B., R. K. Wayne, D. J. Girman, and M. W. Bruford. 1997. A role for ecotones in generating biodiversity. Science 276:1855-1857.

Speck, F. B. 1915. The family hunting band as the basis of Algonkian social organization. American Anthropologist 17:289-305.

Taylor, E. B. 1991. A review of local adaptation in Salmonidae, with particular reference to Pacific and Atlantic salmon. Aquaculture 98:185-207.

Taylor, E. B. 1999. Species pairs of north temperate freshwater fishes: taxonomy, evolution, and conservation. Reviews in Fish Biology and Fisheries 9:299-324.

Taylor, E. B. and J. D. McPhail. 1985. Variation in body morphology among British Columbia populations of Coho salmon, Oncorhynchus kisutch. Canadian Journal of Fisheries and Aquatic Sciences 42:2020-2028.
Turner, N. J., M. B. Ignace, and R. Ignace. 2000. Traditional ecological knowledge and wisdom of aboriginal peoples in British Columbia. Ecological Applications 10:1275-1287.

United Nations Environment Programme (UNEP). 2004. Article 8(j), Secretariat of the Convention of Biological Diversity, Paris, France. Available online at: http://www.biodiv.org/program mes/socio-eco/traditional/default.aspx/.

Usher, P. J. 2000. Traditional ecological knowledge in environmental assessment and management. Arctic 53:183-193.

Waples, R. S. 1995. Evolutionarily significant units and the conservation of biological diversity under the endangered species act. American Fisheries Society Symposium 17:8-27.

Wenzel, G. W. 1999. Traditional ecological knowledge and Inuit: reflections on TEK research and ethics. Arctic 52:113-124. 